\title{
A highly active karstic aquifer bounded by saline waters: The Judea Group aquifer
}

\author{
Ittai Gavrieli ${ }^{1, *}$, Joseph Guttman ${ }^{2}$, Yoseph Yechieli ${ }^{1}$, Firas Talhami ${ }^{3}$, and Avihu Burg ${ }^{1}$ \\ ${ }^{1}$ Geological Survey of Israel, 32 Leibowitz Street., Jerusalem, Israel \\ ${ }^{2}$ Mekorot Water Company, 9 Lincoln Street., Tel Aviv, Israel \\ ${ }^{3}$ Israel Hydrological Service, PO Box 6381, Jerusalem, Israel
}

\begin{abstract}
The freshwater of the Judea Group aquifer that recharges on the crest of the Judea and Samria Mountain ridge flows east and west, defining two groundwater basins. At the foothills of both basins the freshwater encounters ancient saline or brackish water. The mode of interaction between the two water bodies within each basin is different, although both eventually discharge as brackish spring system. We describe these systems and identify the source of the higher salinity end members.
\end{abstract}

\section{Introduction}

The Judea and Samaria Mountains form a north-south elongated ridge that plunges west towards the Mediterranean coast, and east towards the Dead Sea Rift valley (Fig. 1). The latter also hosts the Dead Sea lake that forms the deepest surface on earth (-433 $\mathrm{m}$ in 2018). Structurally, the ridge is formed by a set of anticlines that are part of the Syrian arc structure. The higher parts of this structure are built of the Upper Cretaceous Judea Group which is composed of karstic dolomites and limestones, alternating with some marls and chalks. The Judea Group dips both eastward and westward, where it is overlain by the younger, mainly chalky Mt. Scopus and Avedat Groups of Senonian to Eocene age.

The Judea Group forms an active karstic aquifer of high quality water and is an important source of potable water for the region. The geological sequence implies that at the foothills of the Judea and Samaria Mountains the Judea Group aquifer is confined or roofed under the younger chalky rocks. Recharge to the aquifer takes place along the outcrops on the Mountains' crest and the water flows from there towards three directions that also define three sub-aquifers (Fig. 2):

1: The western Mountain basin (Yarkon-Taninim basin), which captures most of the flow. The water in this basin flows westward from the hydrogeological divide along the crest and upon reaching the lower and confined zones at the foothills turns clockwise towards two natural outlets - the Yarkon and the Taninim springs (Fig. 2). It should be noted that following massive pumping and lowering of the water table, the Yarkon springs no longer discharge and the discharge rate of the Taninim has decreased dramatically.

\footnotetext{
${ }^{*}$ Corresponding author: ittai.gavrieli@gsi.gov.il
} 


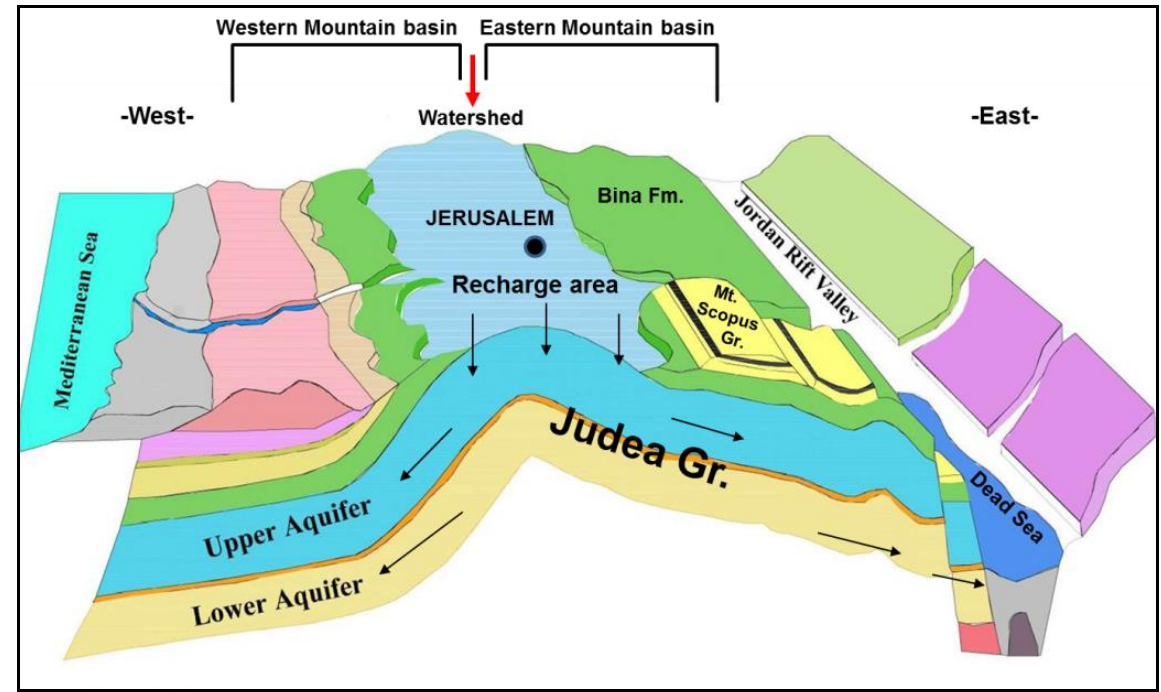

Fig. 1. Schematic geological cross section of the Samaria and Judea Mountains, showing the structural position of the Judea Group aquifer and the separation into the western and eastern basins (after [1]).

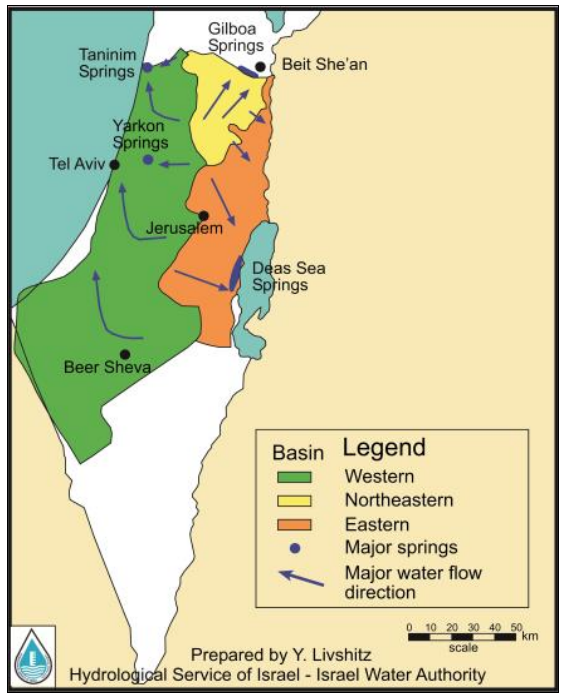

Fig. 2. The three groundwater basins of the Judea Group aquifer (Modified after Y. Livshitz; https://mfa.gov.il/MFA/ForeignPolicy/Peace/Guide/Pages/Water_Israel_Palestinians-Feb_2012.aspx).

2. The eastern mountain basin. Here water flows from the hydrogeological divide eastwards and southeastward towards the Dead Sea Rift valley and discharges in several major springs along the Dead Sea coast. Some water also flows into the younger alluvial fills of the rift valley as well as through smaller perched springs.

3. The northwestern mountain basin: The northern part of the Mountains crest flows northeastwards towards the Beit She'an and Jezreel valleys and discharges through springs within the valley. This part of the system is not under discussion in the present work.

The Judea Group aquifer is highly utilized and numerous wells pump water from all three basins. 


\section{Methods}

Chemical analyses were obtained for well waters in both the eastern and western basins and include new analyses as well as older data existing in a Mekorot Water Company database that are in published reports and papers. The data collected was evaluated based on the major ion composition and ionic ratios. The transition from fresh to saline groundwater bodies was identified using conductivity logs that were carried out by the Israel Hydrological Service in wells containing both fresh and saline groundwater.

\section{Discussion}

Even though the karstic Judea Group aquifer in all basins is highly active with high transmissivities and rapid flows driven by the local Mediterranean climate, its western and eastern margins contain brackish to saline waters. However, the aquifer in the western basin is blocked from the current Mediterranean by a thick impermeable unit, whereas in the east the aquifer is located upstream and higher of the zone of influence of the current Dead Sea. This implies that in both cases the typical fresh-saline interface characteristic of aquifers connected to modern saline water, such as seawater or saline lakes, does not exist. Hence, the presence within the aquifer of the brackish to saline water, albeit at its margins and adjacent to the high quality water of the main aquifer, calls for an explanation for the sources of these water and why they have not yet been flushed out.

\subsection{The western basin}

The saline water in the western basin is similar in composition to slightly diluted seawater. Yet, it is anoxic with presence of $\mathrm{H}_{2} \mathrm{~S}$ and has higher $\mathrm{Mg} / \mathrm{Ca}$ ratio as compared to modern seawater. Recent dating using radiocarbon and ${ }^{81} \mathrm{Kr}$ of this water shows that it is younger than $40 \mathrm{Ka}[1]$. This water body is found in the western margins of the Yarkon-Taninim basin as well as below the freshwater (Fig. 3). Due to the inclined structure, the Judea Group in the western part of the basin is saturated with the saline water, in the eastern part it is filled with freshwater and in the middle a fresh-saline interface exists (Fig. 3). Water flow trajectories of the two bodies are similar [2], both flowing northwards towards the Taninim springs where the two mix. This explains the brackish nature of these springs. The two water bodies show similar changes in water head due to recharge or due to massive pumping from the fresh water body, implying that the two form a single hydrological unit. Electrical conductivity logs show that the interface between the two is in places very sharp (Fig. 4), occurring within a few meters, whereas in others it appears in several steps over few tens of meters. This suggests that there is only limited interaction between the two waters which remain otherwise separated. The age of the water and its similarity to seawater raises the possibility that despite the separation from the Mediterranean by the thick impermeable unit in the west (Fig. 3), there is some inflow of seawater into the saline water body. 


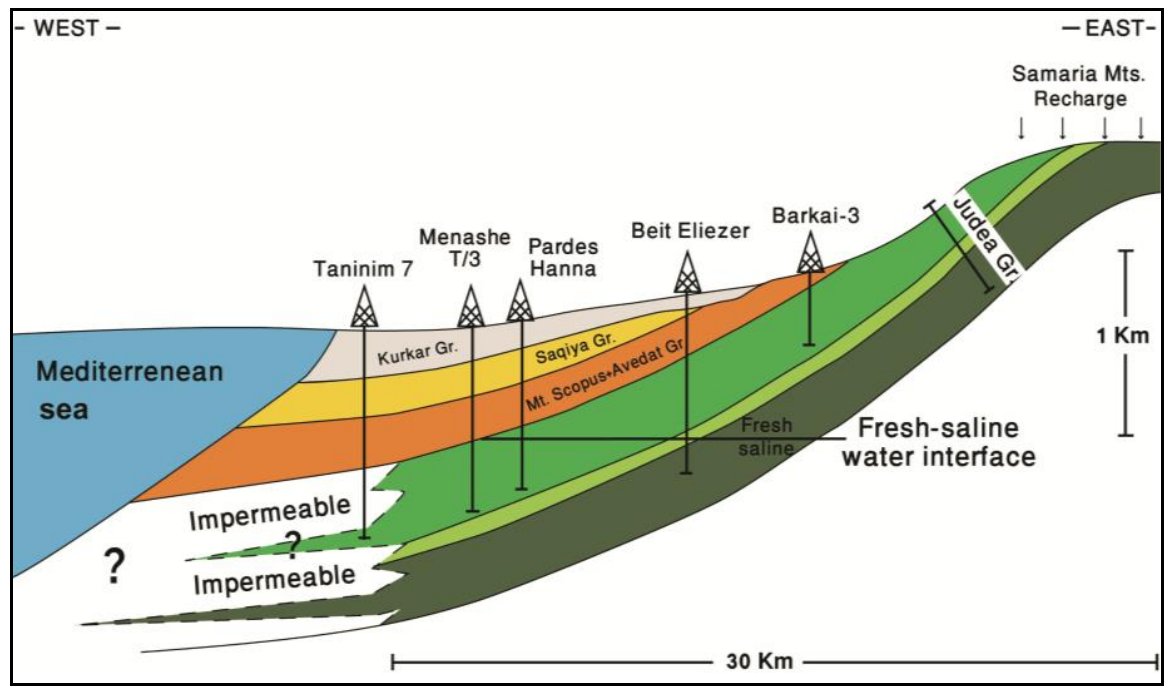

Fig. 3. East-west schematic geological section of the western basin showing the position of the saline and fresh water bodies (from [1]). Note the lateral lithological transition dolomitic-limestone Judea Group aquifer to the impermeable chalky marly unit to the west which restricts seawater inflow westward into the aquifer. The Judea Group is confined by the M. Scopus / Avedat Group which also prevents seawater inflow at the higher part of the section.

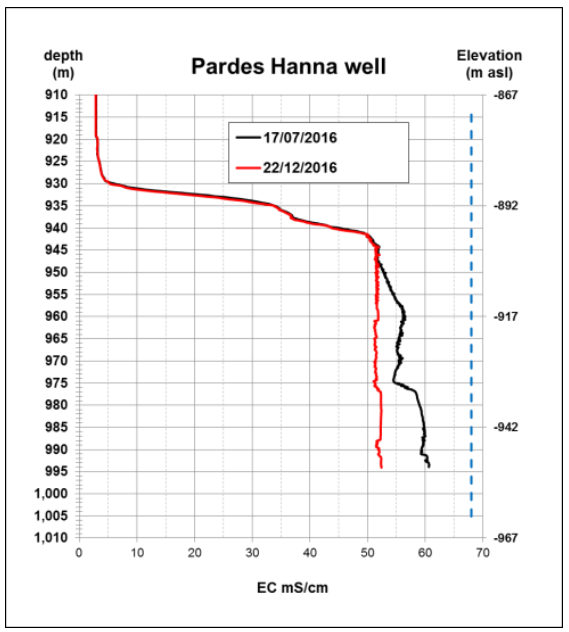

Fig. 4. Electrical conductivity logs in a representative well that crosses the interface between the fresh and saline water bodies in the western basin (from [3]).

\subsection{The eastern basin}

The main outlets of the eastern basin are the brackish springs that emerge along the Dead Sea shores. These waters are characterized by their $\mathrm{Ca}-\mathrm{Cl}$ character $\left(\mathrm{Ca} /\left(\mathrm{HCO}_{3}+\mathrm{SO}_{4}\right)>1 ; \mathrm{Na} / \mathrm{Cl}<1,[4]\right)$, which is different from seawater. Waters and brine of this type are encountered throughout the Dead Sea rift valley with the Dead Sea representing the most saline end member of these types of brines in the region. Wells drilled upstream and northwest of these springs find high quality freshwater (tens of $\mathrm{mg}$ $\mathrm{Cl} / \mathrm{L}$ ) above brackish Ca-chloride waters (thousands $\mathrm{mg} \mathrm{Cl} / \mathrm{L}$ ). Wells north of the Dead Sea 
and adjacent to the Dead Sea fault system encounter freshwater that has slightly higher $\mathrm{Cl}$ concentrations (hundreds of $\mathrm{mg} \mathrm{Cl} / \mathrm{L}$ ) with chemical compositions and ionic ratios typical of the Ca-chloride brines. This range of salinities suggests that the foothill parts of the eastern basin undergoes flushing of an ancient $\mathrm{Ca}$-chloride brine by the freshwater recharged upstream. The efficiency of flushing in the vertical and spatial dimensions is highly variable resulting in different salinities. The source of this ancient brine is attributed to Lake Lisan, the last glacial precursor of the Holocene Dead Sea (70 to15 Ka). The water level of this lake was 200 meters above the present Dead Sea, while its water had salinities of $\sim 100,000 \mathrm{mg} \mathrm{Cl} / \mathrm{L} \mathrm{[5]}$. At this elevation the lake extended along much of the rift valley and was in direct contact with the carbonate rocks of the Judea Group, resulting in penetration of this brine into the aquifer. Since lake level receded at the end of the Pleistocene this brine is being diluted and flushed out continuously.

In summary, the two examples of active karstic freshwater system in contact with ancient saline water bodies exhibit distinctly different interaction modes: Dilution and flushing (the eastern basin) and parallel flow trajectories (western basin). The latter is driven by the hydraulic head of the freshwater with only limited interaction between the two water bodies.

\section{References}

1. Y. Yechieli, et al., Earth Planet Sci Lett, 507, 21-29 (2019)

2. E. Dafny, et al., J Hydrol, 389, 260-275 (2010)

3. A. Burg, F. Talhami, Geol Surv Israel, Rpt GSI/14/2017 (in Hebrew), 28pp (2017)

4. A. Katz, A. Starinsky, Aquatic Geochem, 15, 159-194 (2009)

5. N. Weber, et al., Earth Planet Sci Lett, 493, 242-261 (2018) 